\title{
Analysis of Service Processes Characteristics across a Range of Enterprises
}

\author{
John Maleyeff ${ }^{1}$ \\ ${ }^{1}$ Rensselaer Polytechnic Institute, Hartford Campus. \\ Email: maleyj@rpi.edu
}

Received November $10^{\text {th }}, 2008$; revised January $15^{\text {th }}, 2009$; accepted February $13^{\text {th }}, 2009$.

\begin{abstract}
The structure of services processes was explored using a database of 168 service processes that existed within a wide range of enterprises. The results indicate that applications within service science are not limited to the service industry and that service processes have many similar characteristics. The similarities exist across industry sectors (i.e., manufacturing, service), customer types (i.e., internal, external) and enterprise size (large, SME). A few differences exist and their importance is discussed. It is suggested that an important field within the multidisciplinary umbrella of service science is organizational behavior.
\end{abstract}

Keywords: service science, internal services, service marketing

\section{Introduction}

Service delivery dominates activities performed by the workforce in the United States and other developed countries. For example, in July 2008, $79 \%$ of the U.S. workforce was employed in a service enterprise that was classified as one of the following: retail, government, education, health services, professional, business services, hospitality, leisure, or other services. The remaining $21 \%$ of the U.S. workforce was employed in enterprises classified as farming, manufacturing, construction, or other goods producing [1]. But, of these "goods producing" workers, a significant number are also engaged in service delivery. For example, many workers within manufacturing enterprises provide support or aftermarket services to users of their products (e.g., training, troubleshooting, or maintenance). Further, and perhaps more significantly, "goods producing" workers include internal support providers that deliver value to customers inside the firm. These workers are positioned in various departments such as finance, marketing, engineering, human resources, or information technology.

"Service Science" is an emerging academic discipline created in response to the need for organizations (busi++ ness, industry, non-profits, government, healthcare, etc.) to better understand how to create, manage, and improve services for the benefit of consumers, internal entities, and external partners [2]. The research reported in this article was an effort to contribute to the field of service science by studying the structure of services from a process-oriented perspective derived from lean management principles. Using a database created by the analysis of 168 service processes, the goal was to determine the similarities and differences among service processes that: 1) offer various types of services, 2) deliver value to internal versus external customers, 3) exist within a large versus a small or medium enterprise (SME), 4) consist of transformations that are informational versus not informational, and 5) exist within manufacturing versus service industries.

The results of this research should be useful to managers in both manufacturing and service enterprises, and academic researchers who are concerned with service improvement and service innovation. In the remainder of this article, background is provided that includes results from prior research and recent publications that address a variety of topics within service science, including the classification of services, the management of services for internal customers, and the analysis of service process characteristics. After the research methodology is explained and the resulting data are tabulated, results are described. A discussion follows that places the results in a context appropriate for management decision makers. The paper concludes with recommendations on future research directions.

\section{Background}

Although this research does not set out to create a new classification of services, similar services are combined for purpose of analysis and therefore a review of the relevant literature is warranted. Perhaps the most popular classification scheme was offered by Schmenner [3]. This classification separates services into four types based on two characteristics: 1) the level of customer interaction 
and customization, and 2) the degree of labor intensity. The resulting classification includes the following four sets of service processes (the level of interaction \& customization, and the level of labor intensity is indicated for each): the service factory (low, low), the service shop (high, low), the mass service (low, high), and the professional service (high, high). Fitzsimmons and Fitzsimmons [4] provide a set of challenges that would need to be addressed by managers within each class.

Examples of other classification schemes and related efforts to provide typologies for services have focused on the level of direct customer contact [5], the amount of customer involvement [6], customers' perceptions of services [7], and the amount of customization in the service output [8]. A thorough list of articles that address the classification of services is provided by Cunningham et al. [7].

Whether or not any of the various service classification schemes have enhanced the management of services is an open question. For example, Verma [9] shows that only 4 of 22 important management challenges are affected by the differences in Schmenner's classification scheme. Then again, Silvestro et al. [10] argued that service strategy, control, and performance measurement would differ for professional services, service shops, and mass services. The transition from tangible goods to intangible equivalents, such as maps, videotapes, and newspapers, has also impacted the usefulness of traditional classification schemes [11].

Because the majority of the service processes studied in this research would be classified as an internal service, a review of the relevant literature is warranted. Davis [12] defined internal service operations as "behind-the-scenes routines, procedures, and activities that provide the necessary support to the company's more visible functions." With effects that are often hidden from the view of senior managers, internal services are often the first to be affected by downsizing or outsourcing [13]. The fact that internal service departments sometimes display an attitude that suggests superiority or independence can make them unsympathetic victims within the corporate structure [14].

Research has shown that external customer satisfaction is enhanced by improved internal customer satisfaction [15]. It has been suggested, however, that many organizations are not equipped to understand how to deal with the challenges associated with internal service management [16]. Without a common understanding of how an internal service operates, mistakes are common. For example, technology is often implemented without an understanding of the associated implications [17]. Similarly, an accountant may create budgets that motivate suboptimal behavior due to arbitrary cost allocation schemes [18]. Johnston [15] argues that inadequate attention on internal services. He reported that, in the three major service journals between 1996 and 2006, only 8\% of articles dealt with research into internal services.

The majority of the services analyzed in this research would be classified as a professional service based on
Schmenner's scheme. But, it has been suggested that little agreement exists regarding the definition of a professional service [19]. A definition suggested by Harte and Dale [20], who define a professional service as consisting of "intangible outputs, with qualitative rather than quantitative criteria being the main measures for customer satisfaction, high buyer-interaction levels and lack of heterogeneity," would appear to characterize professional services studied in this research. Professional services are also commonly associated with characteristics such as "specialist knowledge, autonomy, altruism, self-regulation, and a high degree of participation and customization" [21].

Laing and Lian [22] suggest a classification of professional services based on the level of inter-organizational relationships, ranging from almost transactional to a fully integrated. Hausman [23] showed that customer relationships were more important than the professional competence of service providers. Similarly, Day and Barksdale [24] suggest that service providers' understanding of client needs and their communication skills are the main determinants of quality for clients of architectural and engineering firms. And, Ojasalo [25] provides a list of ten characteristics of a professional service based on an extensive literature review. Characteristics such as "a high degree of customer uncertainty" and "affected by characteristics of information", as well as "a problem-solving approach" are notably present in the list. Finally, various mechanisms that weaken customer relationships in professional services have been studied by Ákerlund [26].

In this research, the approach to organizing service processes to explore their underlying characteristics made use of lean management principles [27]. In particular, each transaction within the process is described as being value-added (a task that the customer cannot do or wishes not to do) or non-value-added (other tasks or activities such as inspecting work, moving documents from one department not to another, or various forms of delays). All non-value-added activities would be inherently wasteful, although some may be necessary in the short term due to the structure of the service process (e.g., a delay caused by moving documents from one department to another is necessary if the departments are not co-located).

The use of a lean management approach is motivated by a desire to organize service processes so that groups are created that are likely to make use of similar improvement or innovation approaches. To make an analogy to manufacturing, an effort to reduce the setup time for a drilling process may not be concerned with the overall volume of production. Similarly, in a service, an effort to reduce errors during an information handoff may not be concerned with the whether or not the service offering was standard or customized. An example that illustrates the benefits of this approach is a hospital trauma team that learned how to improve the treatment of emergency patients by studying pit crews at automobile races [28]. 
A qualitative study concluded that services delivered by organizations whose customers were other businesses were similar in structure to those services delivered by organizations whose customers were consumers [15]. But important differences have been reported between services for internal customers and those for external customers. These differences include the lack of choice provided to internal customers [29], limited empathy between service providers and internal customers [30], and inter-departmental dynamics that often lead to misunderstandings of priorities [31].

\section{Methodology}

A total of 168 service systems were included in this study. Each service system was analyzed by a professional employee of the organization who was very familiar with the activities associated with the delivery of the service and had access to customers of the service. Most of the services were primarily for internal customers, but many served primarily external customers, and some served both internal and external customers in about equal measure. No single analyst studied more than one service. All of the analysts were enrolled in a part-time graduate management program on the Hartford, Connecticut campus of Rensselaer Polytechnic Institute, in a three-credit course called Service Operations Management.

The 168 service systems did not constitute a random sample nor were they carefully selected in a controlled experiment. However, the range of firms represented and the services chosen was broad, albeit biased due to the disproportionate number of scientists and engineers in the student body. Sixty-three different enterprises were represented. One large corporation dominated the group, constituting 52 of the 168 services.

For each service system, the analyst was asked to perform a comprehensive study of its structure (by creating a process map or flowchart to illustrate how the various activities interact to provide the service), identify customers as either internal or external (or both), ask several customers to list strengths and weaknesses of the process, and list key performance dimensions important to customers. The resulting reports followed a standard template that allowed for easy tabulation of key results.

A database was created to capture important data related to each service process. It includes, for each service: the name of the enterprise within which the service took place (these data were not available for 8 services), the size of the enterprise (classified as a large enterprise or a $\mathrm{SME}$ ), the type of enterprise-manufacturing or service (these data were not available for 10 services), a brief description of the process, the number of employees directly involved with service delivery (these data were not available for 104 services), the number of departments or functions directly involved with service delivery, the primary type of customer (classified as internal, external, or both), and an indication of whether or not information was the key service transformation. The data were placed into a MINITAB worksheet in preparation for tabulation and statistical analysis.

\section{Service Process Types}

While studying the 168 reports, it became apparent that a finite number of specific types of value-added activities took place, most involving informational transformations. While listing these activities, it was clear that many seemingly dissimilar service possesses consisted of similar sets of transformations (e.g., an audit to determine if a worker is following standard protocol and the testing of a material to determine if it meets specifications both involve evaluation of actual performance and comparison to a standard).

An exhaustive qualitative analysis of the 168 service processes resulted in the classification of six service process types. This set should not be considered comprehensive because the sample of services was not random. It would, however, serve to create an effective analysis structure for this research. Table 1 shows the six service process types, along with examples of each type and the number of occurrences of each type in the database.

Most of the service process types would be classified as a professional service using Schmenner's classification scheme, because they have high levels of both customization and customer contact. In most cases, however, employees delivering a service did not hold strong allegiance to their professions as would, for example, lawyers or physicians. One type that would not always operate as a professional service would be "gathering," the collection and reporting of information that is often disseminated to a wide variety of customers and not always customized for each customer's use. In these cases, the service would be classified as a mass service. A few other examples of services that would not be classified as a professional service would be found in each type.

Table 1. Service process types

\begin{tabular}{|c|c|c|c|}
\hline Type & Description & Examples & No. \\
\hline $\begin{array}{l}\text { Trouble- } \\
\text { shooting }\end{array}$ & $\begin{array}{l}\text { Solves a customer's } \\
\text { problem }\end{array}$ & $\begin{array}{l}\text { IT help desk } \\
\text { Parts return } \\
\text { Root cause investigation } \\
\text { Complains handling }\end{array}$ & 26 \\
\hline $\begin{array}{l}\text { Gathering } \\
\text { (and sub- } \\
\text { sequent } \\
\text { document- } \\
\text { ing) }\end{array}$ & $\begin{array}{l}\text { Provides instructions or } \\
\text { summarizes informa- } \\
\text { tion for use by others }\end{array}$ & $\begin{array}{l}\text { Installation instructions } \\
\text { Maintenance guidelines } \\
\text { Accounting statements } \\
\text { Accident reporting } \\
\text { Environmental Compliance }\end{array}$ & 21 \\
\hline Evaluation & $\begin{array}{l}\text { Determine whether or } \\
\text { not a specification or a } \\
\text { standard is met }\end{array}$ & $\begin{array}{l}\text { Auditing } \\
\text { Design change } \\
\text { Laboratory testing } \\
\text { Part inspection } \\
\text { Bill payment }\end{array}$ & 38 \\
\hline Analysis & $\begin{array}{l}\text { Determine if resources } \\
\text { should be allocated for } \\
\text { a requested purpose }\end{array}$ & $\begin{array}{l}\text { Proposal writing } \\
\text { Sales quoting } \\
\text { Data analysis } \\
\text { New business analysis }\end{array}$ & 20 \\
\hline Planning & $\begin{array}{l}\text { Planning, tracking, and } \\
\text { controlling projects and } \\
\text { other activities }\end{array}$ & $\begin{array}{l}\text { Software integration } \\
\text { Project management } \\
\text { Metric tracking } \\
\text { Employee orientation } \\
\text { Recruitment }\end{array}$ & 40 \\
\hline $\begin{array}{l}\text { Consulta- } \\
\text { tion }\end{array}$ & $\begin{array}{l}\text { Provide specific exper- } \\
\text { tise to assist customers }\end{array}$ & $\begin{array}{l}\text { Tool design } \\
\text { Forecasting } \\
\text { Software development } \\
\text { Supplier selection } \\
\text { Logistic support }\end{array}$ & 23 \\
\hline
\end{tabular}


Table 2. Summary of results by service type

\begin{tabular}{lcccccc}
\hline Service Type (No.) & $\begin{array}{c}\text { Internal } \\
\text { Only }\end{array}$ & $\begin{array}{c}\text { External } \\
\text { Only }\end{array}$ & $\begin{array}{c}\text { Internal \& } \\
\text { External }\end{array}$ & $\begin{array}{c}\text { Average \# } \\
\text { Functions }\end{array}$ & $\begin{array}{c}\text { Median \# } \\
\text { Employees }\end{array}$ & $\begin{array}{c}\text { Information } \\
\text { Delivery }\end{array}$ \\
\hline Troubleshooting (26) & $38 \%$ & $46 \%$ & $16 \%$ & 4.6 & 10.0 & $85 \%$ \\
Gathering (21) & $86 \%$ & $10 \%$ & $4 \%$ & 4.5 & 10.0 & $100 \%$ \\
Evaluation (38) & $79 \%$ & $13 \%$ & $8 \%$ & 4.8 & 16.0 & $100 \%$ \\
Analysis (20) & $70 \%$ & $20 \%$ & $10 \%$ & 5.9 & 14.0 & $100 \%$ \\
Planning (40) & $65 \%$ & $20 \%$ & $15 \%$ & 5.3 & 20.0 & $83 \%$ \\
Consultation (23) & $56 \%$ & $30 \%$ & $14 \%$ & 5.0 & 8.0 & $83 \%$ \\
Overall (168) & $\mathbf{6 6 \%}$ & $\mathbf{2 3 \%}$ & $\mathbf{1 1 \%}$ & $\mathbf{5 . 0}$ & $\mathbf{1 2 . 0}$ & $\mathbf{9 1 \%}$ \\
\hline
\end{tabular}

\section{Analysis \& Results}

Table 2 lists, by type, the percentage of services with primarily internal customers, the percentage of services with primarily external customers, the percentage of services for both internal and external customers, the average number of organizational functions (e.g., internal departments) directly involved with the delivery of the service, the median number of employees directly involved in the delivery of the service, and the percentage of services whose transformations were informational. For the results reported in this section, details on the statistical routines are included in the Appendix.

\subsection{Most Services Served Internal Customers}

Table 2 shows that about two-thirds of services had only internal customers and less than one-fourth of the services had only external customers. The prevalence of services for internal customers was relatively high for all service types, but there was a significant difference in their prevalence across service types $(\mathrm{p}=0.005)$. Specifically, the prevalence of services for internal customers was lower for troubleshooting services. With this category removed, no difference was evident across the service types in the prevalence of services for internal customers $(\mathrm{p}=0.169)$.

\subsection{Services Consist of Inter-Departmental Proc- ess Flows}

Table 2 shows that the number of functions (i.e., departments) involved directly with delivering the service averaged 5.0 functions. And, there was no significant difference in the number of functions across service types $(p=0.684)$. Similarly, the median number of employees directly involved with delivering the service was 12.0, and there was no significantly difference in the number of employees across service types $(p=0.745)$. Figure 1 provides the distribution of the number of functions that participate in delivering each service. It appears to be very likely that a service process will cross more than a few departmental lines within an enterprise.

\subsection{Information Transformations were Dominant}

Table 2 shows that a predominance of informational transformations took place, although some variation existed across service types $(\mathrm{p}=0.012)$. The gathering, evaluation, and analysis service types all consisted exclusively of services that provide information. But, well over
$80 \%$ of services classified as troubleshooting, planning, and consultation also consisted of informational transformations. Examples of cases where information was not the main transformation included the coordination of part's receipt from vendors, the repair of a mechanical device, and the dispensing of drugs by a pharmacy. In all of these services, however, information was an important secondary output that needs to be managed effectively.

\subsection{Services for Internal Customers are Similar to Services for External Customers}

Table 3 shows that, when comparing services meant for internal customers with those meant for external customers, no differences were found in three key characteristics. First, there was no difference in the number of functions involved in service delivery $(\mathrm{p}=0.470)$. Second, there was no difference in the number of employees involved in service delivery $(p=0.653)$. And third, there was no difference in the prevalence of information related services $(\mathrm{p}=0.522)$.

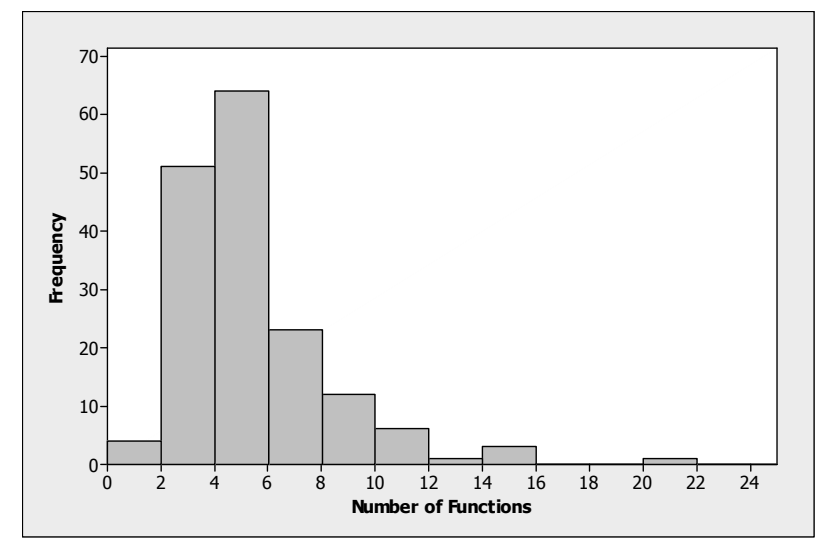

Figure 1. Distribution for number of functions delivering a service

Table 3. Summary of results by customer

\begin{tabular}{cccc}
\hline Customer (No.) & $\begin{array}{c}\text { Average \# } \\
\text { Functions }\end{array}$ & $\begin{array}{c}\text { Median \# } \\
\text { Employees }\end{array}$ & $\begin{array}{c}\text { Information } \\
\text { Delivery }\end{array}$ \\
\hline Internal (111) & 5.2 & 14.0 & $93 \%$ \\
External (38) & 4.6 & 10.0 & $87 \%$ \\
Both (19) & 4.7 & 12.0 & $89 \%$ \\
Overall (168) & $\mathbf{5 . 0}$ & $\mathbf{1 2 . 0}$ & $\mathbf{9 1 \%}$ \\
\hline
\end{tabular}




\subsection{Manufacturing and Service Enterprises Pro- vide Similar Services}

When comparing services found in manufacturing enterprises with those found in service enterprises, the mix of service types was similar $(\mathrm{p}=0.663)$. Table 4 shows that no differences were evident in four key characteristics. First, there was no difference in the mix of customers $(p=0.258)$. Second, there was no difference in the number of functions involved in service delivery $(\mathrm{p}=0.124)$. Third, there was no difference in the number of employees involved in service delivery $(\mathrm{p}=0.344)$. And fourth, there was no difference in the prevalence of information related services $(\mathrm{p}=0.692)$.

\subsection{Large Enterprises and SME's Provide Ser- vices with Some Differences}

When comparing services found in large enterprises with those found in a SME, the mix of service types within the enterprises was similar $(p=0.167)$. Table 5 shows that services found within large enterprises were more likely to have primarily internal customers $(p=0.003)$. But, when comparing services in a large enterprise to services in a SME, no differences were evident in three other key characteristics. First, there was no difference in the number of functions involved in service delivery $(p=0.329)$. Second, there was no difference in the number of employees involved in service delivery $(\mathrm{p}=0.228)$. And third, there was no difference in the prevalence of information related services $(\mathrm{p}=0.756)$.

The results of the analysis of enterprise size were repeated when analyzing data for the large corporation that was disproportionately represented in the sample of services, with one exception. This exception was that, within this corporation, more employees were involved with the delivery of a service ( $\mathrm{p}=0.001)$. Specifically, the median number of employees delivering the service was 40 versus a median of 10 for other organizations. This result may be of interest, because the large corporation operates with a rigorous "standard work" policy that could result in tasks that were easily performed by more than a select few individuals.

\subsection{Services with Information Transformations May be Similar to Other Services}

Table 6 shows that, when comparing the many services that consisted of an informational transformation with the few services that consisted of another type of transformation, no differences were evident in the number of functions involved in service delivery or in the number of employees involved in service delivery. These results should not be considered conclusive, because only 15 of the services involving deliverables other than information.

\section{Discussion}

The study of services, and in particular the field of service science, may have greater relevance than conventional wisdom would dictate. For example, the results detailed above have implications for managers of both manufacturing and services enterprises because few critical differences exist in services found within manufacturing and service enterprises. Perhaps Albrecht [30] was correct in suggesting that the manufacturing-service distinction is becoming blurred and that "the only real distinction anymore is the relative proportion of tangible and intangible value sold and delivered." In addition, services delivered to either internal or external customers, as well as those found in any size organization, possess more similarities than differences.

Table 4. Summary of results by enterprise focus

\begin{tabular}{lcccccc}
\hline Enterprise Focus (No.) & Internal Only & External Only & Internal \& External & $\begin{array}{c}\text { Average \# } \\
\text { Functions }\end{array}$ & $\begin{array}{c}\text { Median \# } \\
\text { Employees }\end{array}$ & Information Delivery \\
\hline Manufacturing (87) & $71 \%$ & $17 \%$ & $12 \%$ & 5.3 & 14.5 & $92 \%$ \\
Services (71) & $62 \%$ & $28 \%$ & $10 \%$ & 4.7 & 10.0 & $90 \%$ \\
Overall (158) & $\mathbf{6 6 \%}$ & $\mathbf{2 3 \%}$ & $\mathbf{1 1 \%}$ & $\mathbf{5 . 0}$ & $\mathbf{1 2 . 0}$ & $\mathbf{9 1 \%}$ \\
\hline
\end{tabular}

Table 5. Summary of results by enterprise size

\begin{tabular}{lcccccc}
\hline Enterprise Size (No.) & Internal Only & External Only & Internal \& External & $\begin{array}{c}\text { Average \# } \\
\text { Functions }\end{array}$ & $\begin{array}{c}\text { Median \# } \\
\text { Employees }\end{array}$ & Information Delivery \\
\hline Large (118) & $74 \%$ & $16 \%$ & $10 \%$ & 5.2 & 15.0 & $92 \%$ \\
Small/Medium (40) & $48 \%$ & $40 \%$ & $12 \%$ & 4.8 & 8.0 & $90 \%$ \\
Overall (158) & $\mathbf{6 6 \%}$ & $\mathbf{2 3 \%}$ & $\mathbf{1 1 \%}$ & $\mathbf{5 . 0}$ & $\mathbf{1 2 . 0}$ & $\mathbf{9 1 \%}$ \\
\hline
\end{tabular}

Table 6. Summary of results by transformation

\begin{tabular}{lccccc}
\hline Transformation (No.) & Internal Only & External Only & Internal \& External & Average \# Functions & Median \# Employees \\
\hline Informational (153) & $67 \%$ & $22 \%$ & $11 \%$ & 5.0 & 12.0 \\
Other (15) & $53 \%$ & $33 \%$ & $14 \%$ & 4.8 & 5.0 \\
Overall (168) & $\mathbf{6 6 \%}$ & $\mathbf{2 3 \%}$ & $\mathbf{1 1 \%}$ & $\mathbf{5 . 0}$ & $\mathbf{1 2 . 0}$ \\
\hline
\end{tabular}


The results also provide some insight into special organizationally-based challenges in service improvement and service innovation. Given the average of 5 functions per service process, it is likely that change efforts would be hampered by ownership confusion, lack of commitment, competing reward systems, and other organizational barriers. Further, an individual manager's motivation to improve a service may be affected by the relatively few employees within each department that take part in the delivery of each service that flows through that department (roughly 2 employees per department). Strong leadership is necessary to overcome organizational barriers and bring cross-functional teams together for improving processes.

The predominance of information transformations in all service types is an important aspect of service improvement and innovation. The importance of information transformations in internal services has been noted previously by Maleyeff [32]. He also offered suggestions on the types of actions that managers should take, including a recommendation to focus improvement efforts on controlling the important information rather than the physical manifestations of information (documents, blueprints, and other tangible forms of service output). The ability to understand and control information flow would appear to be an important skill for managers of any service.

\section{Conclusions \& Future Work}

It would be a mistake to consider the applications within service science to be limited to the service industry. Service processes have similar characteristics, regardless of whether they exist within manufacturing enterprises or service enterprises, and regardless of whether or not the customer is internal or external. Further, with the confirmation that service processes can be expected to flow through more than a few departments within an enterprise, perhaps the most important field within the multidisciplinary umbrella of service science is organizational behavior. It appears that service processes share a number of common characteristics that should interest researchers and practitioners in this field.

Many suggestions may be offered for extending this research. An improved service classification scheme, specifically designed to compliment service improvement and innovation efforts, may be useful. A more thorough and far reaching analysis of the specific value-added tasks that make up service processes could lead to a better understanding of how to modularize efforts at improvement and innovation. That is, perhaps researchers can help find approaches to solve certain problems that have universal rather than local application. It would also be interesting to determine if the results found here would be repeated within a more robust sample of services. Finally, studies of how customer satisfaction is affected by service process characteristics would be helpful. For example, for the large corporation that disproportionately represented the sample studied in this research, does their "standard work" policy translate to higher levels of satisfaction compared with similar enterprises that allow for more flexibility in service delivery?

\section{REFERENCES}

[1] Bureau of Labor Statistics, U. S. department of Labor Newsletter, USDL 08-1049, 2008.

[2] R. C. Larson, "Service science: At the intersection of management, social, and engineering sciences," IBM Systems Journal, 47(1), pp. 41-51, 2008.

[3] Schmenner and W. Roger, "How can service businesses survive and prosper," Sloan Management Review, 27(3), pp. 21-32, 1986.

[4] J. A. Fitzsimmons and M. J. Fitzsimmons, "Service management," 5th Edition, McGraw-Hill, New York, USA, 2006.

[5] R. B. Chase, "The customer contact approach to services: Theoretical bases and practical extensions," Operations Research, 29(4), pp. 698-706, 1981.

[6] U. Wemmerlöv, "A taxonomy for service processes and its implications for system design," International Journal of Service Industry Management, 1(3), pp. 20-40, 1989.

[7] L. F. Cunningham, C. E. Young, W. Ulaga, and M. Lee, "Consumer views of service classification in the USA and France," Journal of Services Marketing, 18(6), pp. 421-432, 2004

[8] D. L. Kellogg and W. Nie, "A framework for strategic service management," Journal of Operations Management, 13, pp. 323-337, 1995.

[9] R. Verma, "An empirical analysis of management challenges in service factories, service shops, mass services, and professional services," International Journal of Service Industry Management, 11(1), pp. 8-25, 2000.

[10] R. Silvestro, L. Fitzgerald, and R. Johnston, "Towards a classification of service processes," International Journal of Service Industry Management, 3(3), pp. 62-75, 1992.

[11] P. Hill, "Tangibles, intangibles and services: A new taxonomy for the classification of output," Canadian Journal of Economics, 32(2), pp. 426-446, 1999.

[12] T. R. V. Davis, "Internal service operations: Strategies for increasing their effectiveness and controlling their cost," Organizational Dynamics, 20(2), pp. 5-22, 1991.

[13] C. R. Jones, "Customer satisfaction assessment for 'internal' suppliers," Managing Service Quality, 6(1), pp. 45-48, 1996.

[14] A. Wilson, "The internal service department-justifying your existence," Logistics Information Management, 11(1), pp. 58-61, 1998.

[15] D. D. Gremler, K. R. Evans, and M. J. Bitner, "The internals service encounter," International Journal of Service Industry Management, 5(2), pp. 34-56, 1994.

[16] R. Johnston, "Internal service-barriers, flows, and assessment," International Journal of Service Industry Management, 19(2), pp. 210-231, 2008. 
[17] P. A. Smart, R. S. Maull, Z. J. Radnor, and T. J. Housel, "An approach for identifying value in business processes," Journal of Knowledge Management, 7(4), pp. 49-61, 2003.

[18] L. Kren, "Planning internal service department resources to avoid suboptimal behavior," The CPA Journal, 78(1), pp. 54-57, 2008.

[19] M. V. Thakor and A. Kumar, "What is a professional service? A conceptual review and bi-national investigation," The Journal of Services Marketing, 14(1), pp. 63-82, 2000.

[20] H. G. Harte and B. G. Dale, "Improving quality in professional service organizations: A review of the key issues," Managing Service Quality, 5(3), pp. 34-44, 1995.

[21] E. Jaakkola and A. Halinen, "Problem solving within professional services: Evidence from the medical field," International Journal of Service Industry Management, 17(5), pp. 409-429, 2006.

[22] A. W. Laing and P. C. S. Lian, "Inter-organizational relationships in professional services: Towards a typology of service relationships," The Journal of Services Marketing, 19(2), pp. 114-127, 2005.

[23] A. V. Hausman, "Professional service relationships: A multi-context study of factors impacting satisfaction, re-patronization, and recommendations," Journal of Services Marketing, 17(3), pp. 226-242, 2003.

\section{Appendix}

Basic statistical tools were incorporated using MINITAB statistical software and the resulting $p$-value is included in the discussion of results. A p-value represents the probability that random chance alone would have produced the effects found in the data. Traditionally, when a $\mathrm{p}$-value is less than $0.05(5 \%)$ the effect is said to be statistically significant.

For analyses to determine if a certain characteristic (e.g., enterprise size, service type) affected the number of functions involved directly in delivering the service, a one-way ANOVA was used. In all of the cases analyzed and reported in this article, homogeneity was confirmed and the resulting residuals were found to be normally distributed with a common variance. A transformation to
[24] E. Day and H. C. Barksdale, "How firms select professional services," Industrial Marketing Management, 21(2), pp. 85-91, 1992.

[25] J. Ojasalo, "Characteristics of professional services and managerial approaches for achieving quality excellence," The Business Review, 7(2), pp. 61-68, 2007.

[26] H. Ákerlund, "Fading customer relationships in professional services," Managing Service Quality, 15(2), pp. 156-171. 2005.

[27] J. P. Womack and D. T. Jones, "Lean Thinking," 2nd Edition. Free Press, New York, USA, 2003.

[28] G. Naik, "New formula: A hospital races to learn lessons of Ferrari pit stop," Wall Street Journal, A1, November 14, 2006.

[29] P. J. A. Nagel and W. W. Cilliers, "Customer satisfaction: A comprehensive approach," International Journal of Physical Distribution \& Logistics Management, 20(6), pp. 2-46, 1990.

[30] K. Albrecht, "The service within," McGraw-Hill, New York, NY, USA, 1990.

[31] S. Auty and G. Long, "'Tribal warfare' and gaps affecting internal service quality," International Journal of Service Industry Management, 10(1), pp. 7-22, 1999.

[32] J. Maleyeff, "Exploration of internal service systems using lean principles," Management Decision, 44(5), pp. 674-689, 2006.

the natural $\log$ of the number of functions was necessary to ensure normality of residuals.

Mood's median test was used for analyses to determine if a certain characteristic (e.g., enterprise size, service type) affected the number of employees involved directly in delivering the service (a one-way ANOVA was not used because the distribution of the number of employees was highly skewed and a few outliers existed). For analyses to determine if a certain characteristic (e.g., enterprise size, service type) affected a binary variable (e.g., internal or external customer, informational or not informational), a two-sample hypothesis test for proportions was used. Chi-square hypothesis tests were used for analyses to determine if differences in the service types affected a certain binary variable (e.g., prevalence of internal customers, prevalence of informational transformations). 